\title{
Glycogen depletion and altered copper and manganese handling in Nephrops norvegicus following starvation and exposure to hypoxia
}

\author{
S. P. Baden ${ }^{1}$, M. H. Depledge ${ }^{2 *}$, L. Hagerman ${ }^{3}$ \\ ${ }^{\ddagger}$ University of Göteborg, Kristineberg Marine Research Station, S-45034 Fiskebäckskil, Sweden \\ ${ }^{2}$ Odense University, Ecotoxicology Group, Institute of Biology, DK-5230 Odense M, Denmark \\ ${ }^{3}$ University of Copenhagen, Marine Biological Laboratory, DK-3000 Helsingor, Denmark
}

\begin{abstract}
Nephrops norvegicus exposed to starvation and hypoxia in the field as well as in the laboratory exhibited marked differences in glycogen reserves, haemolymph haemocyanin concentrations, and tissue copper and manganese contents. Muscle glycogen concentration was reduced by ca $50 \%$ in lobsters collected from hypoxic field conditions. Glycogen concentrations were reduced to ca $3 \%$ of initial values in muscle and $10 \%$ in midgut gland following 7 mo starvation in the laboratory. Haemolymph haemocyanin concentration was markedly reduced in $N$ norvegicus exposed to severely hypoxic conditions although haemolymph copper concentration remained virtually unchanged. Starvation resulted in a slower reduction of haemocyanin concentration than was associated with hypoxia. Starvation resulted in a net loss of copper after 7 mo. Experimental exposures to moderate or severe hypoxia were not associated with net losses of copper, although in long-term moderate hypoxia the whole body copper load was redistributed, especially to the midgut gland increasing the concentration there 4 times. Redistribution of copper to the midgut gland did not occur in $N$ norvegicus exposed to severe hypoxia in the field. Threeto four-fold lower copper concentrations were found in the midgut glands of hypoxic lobsters (compared to controls from normoxic areas). As well as low copper concentrations, these lobsters had 2 to 4 times higher manganese concentrations in internal tissues. In the absence of sediment, manganese concentrations and contents were not influenced by laboratory exposure to hypoxia.
\end{abstract}

KEY WORDS: Copper - Manganese $\cdot$ Haemocyanin - Glycogen $\cdot$ Hypoxia $\cdot$ Starvation $\cdot$ Nephrops norvegicus

\section{INTRODUCTION}

Over the last $10 \mathrm{yr}$, large areas of the southeastern Kattegat $\left(57^{\circ} \mathrm{N}, 12^{\circ} \mathrm{E}\right)$ have experienced periods of hypoxia (oxygen concentration $<20 \%$ saturation), especially during autumn (Rydberg 1987, Baden et al. 1990a). This has been attributed to increased coastal eutrophication (Rosenberg et al. 1990). The area involved (ca $4000 \mathrm{~km}^{2}$ ) formerly constituted an important fishing ground for the lobster Nephrops norvegicus. Currently, however, the size of the $N$. norvegicus population has fallen to such an extent that commercial fishing is no longer viable. The reasons underlying this decline are complex. Effects of severe hypoxia (oxygen

\footnotetext{
- Present address: Department of Biological Sciences, University of Plymouth, Drake Circus, Plymouth PL4 8AA, UK
}

concentration $<15 \%$ saturation) and prolonged moderate hypoxia on $N$. norvegicus in situ were reported by Hagerman \& Baden (1988) and Baden et al. (1990b). Haemolymph haemocyanin concentrations were low in lobsters newly collected from hypoxic sites. Earlier laboratory studies in which lobsters Homarus vulgaris were exposed to prolonged, moderate hypoxia in experimental aquaria indicated that compensatory respiratory adjustments, including increases in ventilation (Butler et al. 1978) and haemolymph haemocyanin concentration may occur. Hagerman \& Uglow (1985) reported similar findings for $N$. norvegicus maintained in moderately hypoxic conditions. Compensatory responses, however, occurred only if animals were fed (Crangon crangon; Hagerman 1986). N. norvegicus experiencing hypoxic conditions in situ are apparently in such a poor nutritional state (Hagerman \& Baden 
1988, Baden et al. 1990b) that physiological changes normally associated with starvation are superimposed on responses to hypoxia alone.

Depledge \& Bjerregaard (1989) reviewed changes in haemolymph and tissue copper concentrations in decapod crustaceans associated with starvation. Haemolymph haemacyanin concentration and copper concentration usually fall as nutritional state declines. This is associated with a concomitant increase in midgut gland copper concentration, although not all of the copper lost from the haemolymph is necessarily accommodated in the midgut gland (Depledge \& Bjerregaard 1989). Other changes in starved benthic crustaceans maintained in hypoxic conditions include depletion of glycogen reserves (Hagerman \& Szaniawska 1990), reduced locomotor activity and a marked rise in perfusion index $\left(\dot{Q} / \dot{V}_{\mathrm{O}_{2}}\right)$ consistent with reduced haemocyanin concentrations in haemolymph (Depledge 1985).

Nephrops norvegicus with black $\mathrm{MnO}_{2}$ deposits on the gills and lesions on the carapace were found after hypoxic periods in the Kattegat (Baden et al. 1990b). The bioavailability of reduced manganese increases in severely hypoxic conditions (Hall et al. 1989, Garringa 1991) which may influence its distribution among tissues and the physiological processing of other metabolites. The aim of the present study was to investigate changes in the utilisation and tissue distribution of glycogen, together with the handling of selected trace metals (copper and manganese) in $N$. norvegicus exposed to different degrees of hypoxia and starvation in situ and in the laboratory

\section{MATERIALS AND METHODS}

Laboratory studies. Creel-caught Nephrops norvegicus (males and females, carapace length 30 to $60 \mathrm{~mm}$, mean fresh weight $62 \mathrm{~g}$ ) were collected from normoxic conditions ( $40 \mathrm{~m}$, Skagerrak) from late September to late November 1990 and in March and April 1991.

In the laboratory Nephrops norvegicus were exposed to varying degrees of hypoxia (oxygen concentration in \% saturation) and exposure time: $7 \%$ (3 d) and $10 \%$ ( $6 \mathrm{~d}$ ) during autumn 1990 and $12 \%$ (12 d) and $15 \%$ (34 d) during spring 1991. Groups of lobsters were subjected to starvation in normoxic conditions for similar periods and regarded as controls. An additional group was starved for 7 mo (October 1990 to April 1991). The oxygen concentrations used in these experiments were derived from previous experiments where exposure to oxygen concentrations of 10 to $20 \%$ saturation resulted in a wide span of tolerance in $N$. norvegicus. Similar oxygen concentrations are also found in the field during hypoxic periods for 1 to 3 mo each autumn (Baden et al. 1990b). Exposure time for each group depended on the time it took for the lobsters to become moribund (sluggish, not standing with legs erected, responding slowly when touched and with the normal translucent muscle tissue appearing whitish).

PVC tanks ( $1 \mathrm{~m}^{3}$ ) containing 300 to $400 \mathrm{l}$ of seawater, but no sediment, were used to hold test lobsters ( 8 to 10 per tank). Temperature was maintained in the range 8 to $10^{\circ} \mathrm{C}$ and salinity between 32 and $34 \mathrm{ppt}$.

Vigorous aeration was used to maintain ca $100 \%$ oxygen saturation in tanks containing controls. Other specified oxygen concentrations were obtained by bubbling nitrogen-enriched air through seawater. Gas mixing and adjustment of oxygen concentration were achieved in $2 \mathrm{~m}$ high and $0.3 \mathrm{~m}$ diameter cylinders connected to the experimental tanks. Stable oxygen concentrations were set using a feedback system involving a gas regulator (E. Larsen, Århus University, Denmark) connected to an oxygen meter (YSI model 58). Winkler titrations were carried out every $2 \mathrm{~d}$ to check the calibration of the oxygen meter.

Field studies. The test lobsters comprised the following

(1) Controls: 10 Nephrops norvegicus collected from normoxic waters in the Skagerrak, west of Gullmarsfjord, in late November 1990

(2) Moderate hypoxia (oxygen concentration $<30 \%$ saturation): 15 individuals collected at the mouth of Gullmarsfjord in the eastern Skagerrak. At the time of collection (October 1990), the bottom waters in this locality had oxygen concentrations of ca 20 to $30 \%$ saturation (Lindahl pers. comm. j.

(3) Severe hypoxia (oxygen concentration $<20 \%$ saturation): 9 individuals from the southeastern Kattegat. Five of these individuals were taken from waters with an oxygen concentration between 15 and $20 \%$ saturation while the remaining 4 individuals were collected from waters having an oxygen concentration of ca $12 \%$ saturation.

Nephrops norvegicus collected from the field were sampled for haemolymph and then frozen. Dissection and freeze-drying of tissues were cdrried out within 2 wk.

In 1990, the bottom waters of the southeastern Kattegat were hypoxic from mid-August until late October. Oxygen concentration was $<30 \%$ saturation throughout this period and $<20 \%$ saturation from the beginning of September. Lowest recorded oxygen concentrations (ca 12\% saturation) occurred at the end of September (L. Edler, Swedish Meteorological and Hydrographical Investigations, pers. comm.), coinciding with the time at which the lobsters were collected. The small sample size reflects the depleted lobster population in this area 
Analytical protocol. Glycogen analysis: Glycogen concentrations were determined in samples of abdominal muscle and midgut gland. Tissue subsamples (100 mg dry weight) were boiled with $0.5 \mathrm{ml}$ of $20 \%$ potassium hydroxide for $20 \mathrm{~min}$. After cooling, $5 \mathrm{ml}$ of $96 \%$ ethanol were added and samples stored for $24 \mathrm{~h}$ in a refrigerator Following centrifugation, the precipitate was extracted twice with trichloroacetic acid, combined and again precipitated with $2 \mathrm{ml}$ of ethanol. The fluid phase was removed and the precipitate redissolved in $1 \mathrm{ml}$ of distilled water. Glycogen was then measured by the anthrone-reagent method described by Vooys (1987).

Haemolymph haemocyanin concentrations: Haemolymph samples $(0.3$ to $0.5 \mathrm{ml})$ were taken at the beginning and end of each experiment. The needle of a hypodermic syringe was inserted through the arthrodial membrane at the base of the fifth walking leg and haemolymph carefully withdrawn. Samples were then rapidly frozen and stored for later analysis.

To measure oxyhaemocyanin concentration, the samples were thawed and 100 to $200 \mu \mathrm{l}$ subsamples of haemolymph were diluted with $1 \mathrm{ml}$ of distilled water in a $10 \mathrm{~mm}$ quartz cuvette. The absorbance of each subsample was measured at a wavelength of $335 \mathrm{~nm}$ using a spectrophotometer (UV 2100 Shimadzu, Japan). A millimolar extinction coefficient of 17.26 was used (calculated from data for a haemocyanin subunit of 75000 daltons (Nickerson \& van Holde 1971, Antonini \& Brunori 1974) to calculate oxyhaemocyanin concentration. There is a small possibility that this method slightly overestimates the oxygen concentration due to light scattering. Relative changes are, however, not influenced by this.

Metal analysis: The concentrations of copper and manganese were determined in subsamples of freezedried midgut gland, muscle and exoskeleton, and in haemolymph, by atomic absorption spectrophotometry [Perkin-Elmer $2380+$ hollow cathode lamps; see Bjer- regaard \& Vislie (1986) and Depledge (1989a) for further details]. The haemolymph from field lobsters that had experienced oxygen concentrations $<30 \%$ and $<12 \%$ saturation were unfortunately lost in transit. Thus, while haemocyanin concentrations were determined, metal analyses could not be carried out.

Tissue proportions: Depledge (1989a) has pointed out that concentration changes alone are insufficient to provide an overview of metal handling in crustaceans. Changes in the metal content of whole tissues must also be assessed. This necessitates measuring the relative and absolute amounts of whole tissues in animals.

Tissue proportions (Table 1) were determined in 60 Nephrops norvegicus on a wet weight basis. The following tissues were dissected out whole: midgut gland (MG), muscle (M), exoskeleton (E) and remaining soft parts (RSP). The free haemolymph (i.e. haemolymph that was not trapped in tissues) was estimated as the difference between the wet weight of the whole lobster and the wet weight of the dissected and blotted tissues for the above categories. The metal content of each tissue was calculated by multiplying tissue wet weight by the tissue metal concentration.

Statistical analysis. Differences in the concentrations of glycogen, oxyhaemocyanin, copper and manganese among the experimental groups were tested for significance using a 1 -factor ANOVA after testing for homogeneous variance usings Cochran's test. For non-homogeneous variances, the Mann-Whitney $U$-test was used with 2 independent series of data, the Wilcoxon matched-pairs signed ranks test between 2 dependent series and the Kruskal-Wallis test between 3 or more independent series (Zar 1984). When the null hypothesis of a test was rejected, an a posteriori analysis was carried out with Scheffe's test after ANOVA, and a non-parametric multiple comparisons test after the Kruskal-Wallis test (Zar 1984). The criterion for significance was $\mathrm{p}<0.05$.

Table 1. Nephrops norvegicus. Tissue proportions (mean \% tissue wet wt of total body wet wt, SE) for: autumn, experiments with oxygen concentrations of $7 \%$ and $10 \%$ saturation and from field with $<30 \%$ and $100 \%$ saturation; spring, experiments with oxygen concentrations of $12 \%$ saturation and from field with $100 \%$ saturation; starved, experiments with oxygen concentrations of $15 \%$ saturation and starvation in $7 \mathrm{mo}$; and from Kattegat during autumnal (A) hypoxia (<0\%, <12\% saturation). RSP: remaining soft parts. Haemolymph proportion is the non-tissue part of the haemolymph

\begin{tabular}{|c|c|c|c|c|c|c|c|c|}
\hline \multirow[t]{2}{*}{ Tissue } & \multicolumn{2}{|c|}{$\begin{array}{l}\text { Autumn } \\
\mathrm{n}=35\end{array}$} & \multicolumn{2}{|c|}{$\begin{array}{l}\text { Spring } \\
\mathrm{n}=12\end{array}$} & \multicolumn{2}{|c|}{$\begin{array}{c}\text { Starved } \\
n=7\end{array}$} & \multicolumn{2}{|c|}{$\begin{array}{c}\text { Kattegat (A) } \\
n=6\end{array}$} \\
\hline & $\bar{X}$ & $\mathrm{SE}$ & $\bar{X}$ & SE & $\bar{X}$ & $\mathrm{SE}$ & $\bar{X}$ & $\mathrm{SE}$ \\
\hline Muscle & 41.67 & 0.39 & 40.32 & 1.04 & 38.14 & 0.70 & 41.00 & 0.96 \\
\hline Midgut gland & 4.84 & 0.21 & 3.52 & 0.23 & 1.70 & 0.12 & 3.98 & 0.21 \\
\hline Haemolymph & 16.53 & 0.71 & 18.54 & 1.44 & 24.85 & 1.17 & 16.81 & 2.27 \\
\hline Exoskeleton & 29.24 & 0.63 & 30.59 & 0.75 & 29.63 & 0.90 & 29.23 & 1.32 \\
\hline RSP & 7.72 & 0.39 & 7.02 & 0.42 & 5.68 & 0.35 & 9.00 & 0.30 \\
\hline
\end{tabular}




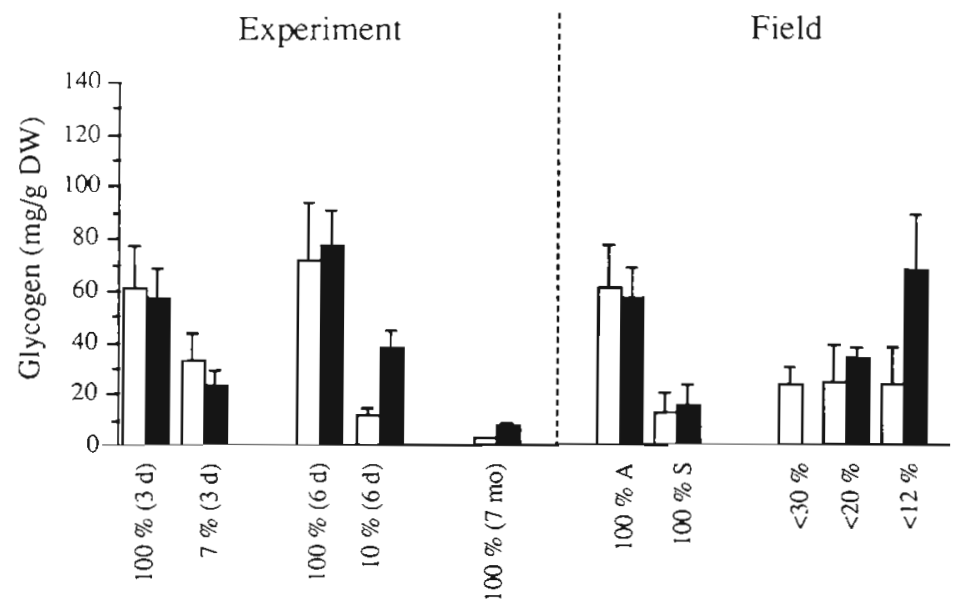

Fig. 1. Nephrops norvegicus. Mean (+ SE) muscle (white bars) and midgut gland (black bars) glycogen concentrations ( $\mathrm{mg} \mathrm{g}^{-1}$ dry wt) from lobsters exposed to normoxia and various degrees of hypoxia (specified as oxygen concentrations in \% saturation) in experiments and field. Exposure time in days is given in parentheses. A: autumn; $S$ : spring

\section{RESULTS}

\section{Effects on glycogen}

Glycogen concentrations in muscle and midgut gland exhibited marked inter-individual variability. Nephrops norvegicus exposed to experimental hypoxia showed significant reductions in glycogen concentration. In control lobsters, the mean muscle glycogen concentration was $72 \pm 17.5 \mathrm{mg} \mathrm{g}^{-1}$ dry wt (mean $\pm \mathrm{SE}$ ). Exposure for $6 \mathrm{~d}$ to an oxygen concentration of $10 \%$ saturation was associated with an $85 \%$ reduction in muscle glycogen concentration (compared to controls; Fig. 1). Exposure to oxygen concentrations of $7 \%$ and $10 \%$ saturation for 3 and $6 \mathrm{~d}$ respectively resulted in a 50 to $60 \%$ fall in midgut gland glycogen concentration.

Starvation for 7 mo in the laboratory was associated with marked decreases in both muscle and midgut gland glycogen concentrations. Values were only $3 \%$ and $10 \%$, respectively, of those measured in nonstarved individuals.
Nephrops norvegicus collected from 3 hypoxic field sites had lower (mean \pm SE: $23.4 \pm 0.26 \mathrm{mg} \mathrm{g}^{-1}$ dry wt) muscle glycogen concentrations than controls (normoxic lab or field specimens collected in the autumn). The muscle glycogen concentration was not significantly different from that found in lobsters starved for 7 mo or in field lobsters collected in the spring.

\section{Effects on haemolymph haemocyanin}

Exposure to oxygen concentrations of $7 \%$ and $10 \%$ saturation for 3 and 6 d respectively led to a reduction in haemocyanin concentration of up to $60 \%$, compared to controls, but no change in haemocyanin concentration was detected after $12 \mathrm{~d}$ in $12 \%$ and $34 \mathrm{~d}$ in $15 \%$ oxygen saturation. Both initial and final concentrations are shown.

Exposure of lobsters to varying degrees of environmental hypoxia resulted in significantly lower (ca 30\%) haemocyanin concentrations than measured in Nephrops norvegicus taken from normoxic conditions (Fig. 2).

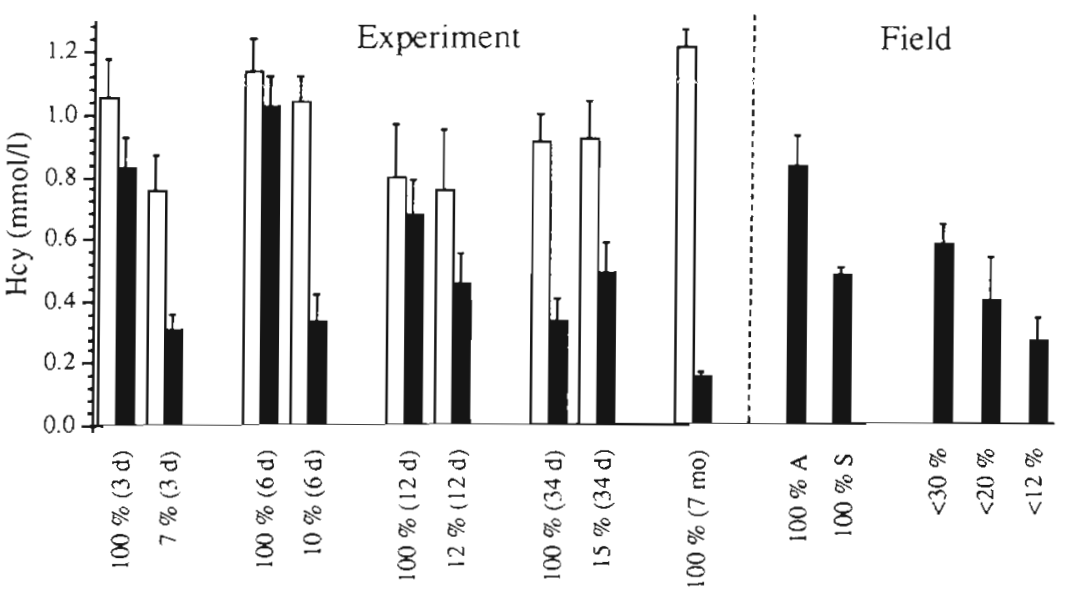

Fig. 2. Nephrops norvegicus. Mean (+ SE) haemolymph haemocyanin concentrations (mmol $1^{-1}$ ) before experiment (white bars) and after experiment or from field (black bars) from lobsters exposed to normoxia and various degrees of hypoxia (specified as oxygen concentrations in \% saturation) in experiments and field. Exposure time in days is given in parentheses. A: autumn; 
Starvation in normoxic conditions for more than $12 \mathrm{~d}$ and exposure to hypoxia were, in general, associated with significant reductions in haemocyanin concentration. Values decreased to only $13 \%$ of the initial haemocyanin concentration after 7 mo starvation.

\section{Effects on metal handling}

Copper. Copper concentrations in muscle tissue were in the range 25 to $47 \mu \mathrm{g} \mathrm{g}^{-1}$ dry wt. Exposure to hypoxia and starvation had little effect on muscle copper. In contrast, in the midgut gland, mean ( $\pm \mathrm{SE}$ ) copper concentration increased from ca $153 \pm 24 \mu \mathrm{g} \mathrm{g}^{-1}$ dry wt in autumn to ca $325 \pm 55 \mu \mathrm{g} \mathrm{g}^{-1}$ dry wt in spring. Nephrops norvegicus exposed to an oxygen concentration $<12 \%$ saturation in the field had a mean midgut gland copper concentration of only $57 \pm 10 \mu \mathrm{g} \mathrm{g}^{-1} \mathrm{dry}$ wt. Values were markedly elevated (mean $\pm \mathrm{SE}$ : $626 \pm$ 167 and $1313 \pm 364 \mu \mathrm{g} \mathrm{Cu} \mathrm{g}{ }^{-1}$ dry wt) in the midgut glands of lobsters exposed to oxygen concentrations of $12 \%$ and $15 \%$ saturation for 12 or $34 \mathrm{~d}$, respectively. Starvation for 7 mo in normoxic conditions resulted in elevation of the mean midgut gland copper concentra-

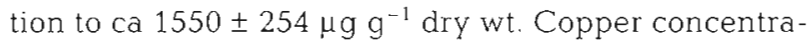
tion in the haemolymph did not change significantly with exposure to hypoxia (oxygen concentration of $12 \%$ and $15 \%$ saturation for 12 and 34 d respectively) or with starvation in normoxic conditions for 12 to $34 \mathrm{~d}$. Haemolymph copper concentration varied from 61 to $96 \mu \mathrm{g} \mathrm{ml}^{-1}$ Haemolymph copper concentrations in $\mathrm{N}$. norvegicus starved for 7 mo were as low as $30 \mu \mathrm{g} \mathrm{ml}^{-1}$.

The relationship between oxyhaemocyanin concentration (measured spectrophotometrically) and haemolymph copper concentration in field lobsters not subjected to hypoxia was described by the equation:

$$
\begin{gathered}
{[\mathrm{Cu}]\left(\mu \mathrm{g} \mathrm{ml}^{-1}\right)=59.18[\mathrm{oxyHc}]\left(\mathrm{mmol} \mathrm{l}^{-1}\right)+17.18} \\
\left(\mathrm{r}^{2}=0.73, \mathrm{n}=51\right) .
\end{gathered}
$$

It was particularly interesting to note that in Nephrops norvegicus exposed to starvation for $34 \mathrm{~d}$ or hypoxia oxyhaemocyanin concentration decreased significantly, whereas no significant change in haemolymph copper concentration was detected.

Copper concentrations in the exoskeleton were lower during spring (ca $11 \pm 3 \mu \mathrm{g} \mathrm{g}^{-1}$ dry wt) than autumn (ca $23 \pm 3 \mu \mathrm{g} \mathrm{g}^{-1}$ dry wt) and lower (14 to $19 \mu \mathrm{g}$ $\mathrm{g}^{-1}$ ) in areas where oxygen concentration was $<20 \%$ saturation.

Manganese. No significant changes in tissue manganese concentration occurred during exposure to experimental hypoxia. Muscle concentrations were between 1.1 to $2.7 \mu \mathrm{g} \mathrm{g}^{-1}$ dry wt while in midgut gland, concentrations were in the range 3.1 to $6.2 \mu \mathrm{g} \mathrm{g}^{-1}$ dry wt, with highest values recorded in spring. The exoskeleton concentration was low in spring (mean $\pm \mathrm{SE}=$ $97 \pm 13 \mu \mathrm{g} \mathrm{g}^{-1}$ dry wt) but rose to higher values (273 \pm $24 \mu \mathrm{g} \mathrm{g}^{-1}$ dry wt) during autumn.

Overall, manganese concentrations in muscle $15.9 \pm$ $0.99 \mu \mathrm{g} \mathrm{g}^{-1}$ dry wt) and midgut gland (14 $\pm 2.94 \mu \mathrm{g} \mathrm{g}^{-1}$ dry wt) were significantly higher in lobsters collected from hypoxic sites compared to concentrations found in animals from normoxic sites.

With regard to haemolymph concentrations, values in Nephrops norvegicus from normoxic sites in or exposed to normoxia in the laboratory were less than $1 \mu \mathrm{g} \mathrm{Mn} \mathrm{ml}^{-1}$ while haemolymph manganese concentrations in lobsters collected from hypoxic field sites were ca $3 \mu \mathrm{g} \mathrm{Mn} \mathrm{ml} \mathrm{Ml}^{-1}$.

\section{Tissue metal loads}

To establish changes in tissue loads of copper and manganese, metal concentrations were converted and expressed on a wet weight basis using the mean wet weight/dry weight ratios determined for each tissue in each group of treatments. Note that only 4 tissues are considered (haemolymph, exoskeleton, muscle and midgut gland) as they represent 91 to $94 \%$ of the wet weight of each lobster (Table 1) and are known to be involved in metal handling. The role of the remaining soft parts is minor, at least with regard to metal storage (see Depledge \& Bjerregaard 1989). By adding together copper loads of free haemolymph, exoskeleton, muscle and midgut gland rough estimates of copper loads of lobsters in different conditions could be deduced. To facilitate comparison of individual tissue metal loads in lobsters that had been exposed to different conditions, all data are presented for hypothetical standard weight (100 g wet $w \mathrm{t}$ ) individuals (Figs. 3 \& 4). In normoxic conditions the whole body copper loads of Nephrops norvegicus amounted to ca 2500 to $3000 \mu \mathrm{g} \mathrm{Cu}$. Copper load was apparently relatively constant in the different experimental and environmental conditions (Fig. 3). A translocation of copper from the haemolymph to the midgut gland occurred in lobsters exposed to oxygen concentrations of $12 \%$ and $15 \%$ saturation for 12 and $34 \mathrm{~d}$ respectively. Furthermore, in individuals collected from hypoxic areas (oxygen concentrations $<12 \%$ saturation) in autumn, the midgut gland was almost entirely depleted of copper.

Changes in the manganese contents of Nephrops norvegicus exposed to different degrees of hypoxia and starvation are summarised in Fig. 4. Lobsters collected from moderately and severely hypoxic sites in situ had high manganese contents (Fig. 4). Whole body manganese contents were 2 to 3 times higher than in lobsters from normoxic areas. 


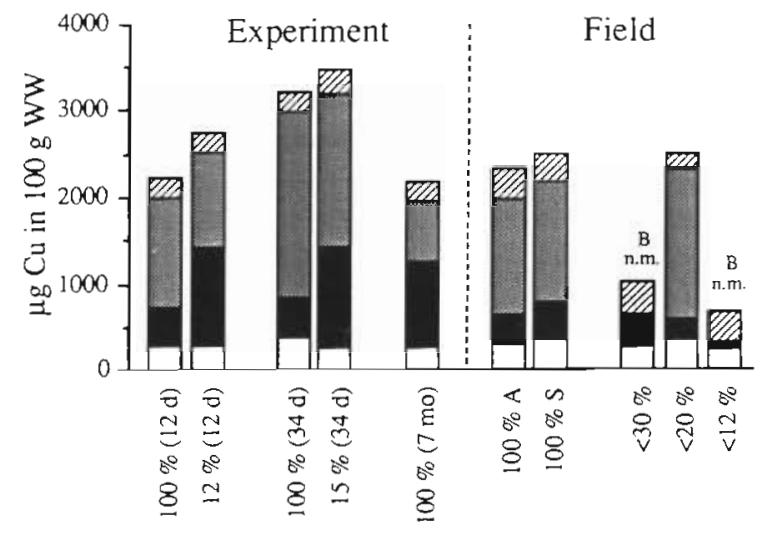

Fig. 3. Nephrops norvegicus. Mean tissue load of copper ( $\mu \mathrm{g}$ $\mathrm{Cu}$ ) in exoskeleton (hatched), haemolymph (dotted), midgut gland (black) and muscle (white) calculated for a hypothetical individual of $100 \mathrm{~g}$ fresh weight. Results are taken from analysis of $\mathrm{Cu}$ from lobsters exposed to normoxia and various degrees of hypoxia (specified as oxygen concentrations in $\%$ saturation] in both experiments and field. Exposure time in days is given in parentheses. A: autumn; S: spring; B n.m.: blood not measured

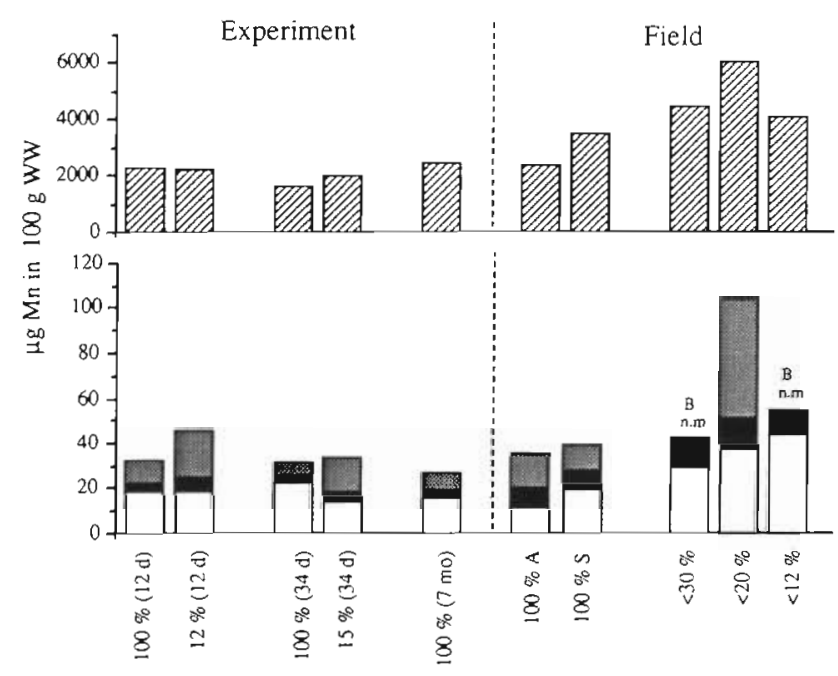

Fig. 4. Nephrops norvegicus. Mean tissue load of manganese ( $\mu \mathrm{g} \mathrm{Mn}$ ) in exoskeleton (hatched), haemolymph (dotted), midgut gland (black) and muscle (white) calculated for a hypothelical individual of $100 \mathrm{~g}$ fresh weight. Results are taken from analysis of $\mathrm{Mn}$ from lobsters exposed to normoxia and various degrees of hypoxia (specified as oxygen concentrations in \% saturation) in both experiments and field. Exposure time in days is given in parentheses. A: autumn S: spring; B n.m.. blood not measured

Lobsters exposed to experimental hypoxia in the laboratory did not exhibit significant changes in manganese content. Small variations were attributable mainly to altered muscle content. In individuals starved for 1 mo in the laboratory, whole body manganese contents were slightly elevated, reflecting an increase in muscle manganese. However, after 7 mo starvation no differences in manganese content or distribution were evident when compared with controls.

\section{DISCUSSION}

Hypoxia associated with eutrophication poses a severe threat to epifaunal crustaceans (Atkinson \& Taylor 1988, Hagerman \& Baden 1988, Baden et al. 1990 b, Rosenberg et al. 1991). The present study indicates that several factors may interact to produce physiological stress in animals exposed to such conditions.

Nephrops norvegicus collected from normoxic field sites exibited considerable inter-individual variability in glycogen concentration. Nonetheless, the range of values obtained corresponds well with the normal range given for crustaceans in the literature (ca 4 to $6 \mu \mathrm{mol} \mathrm{g}^{-1}$ dry wt in muscle and midgut gland; de Zwaan \& Putzer 1985).

Glycogen is a readily mobilized storage form of glucose (Stryer 1988). Glycogen depletion, especially in muscles, was seen following exposure to oxygen deficiency or starvation. This is consistent with earlier suggestions that muscle contains a particularly important store of glycogen as it is more readily accessible when anaerobic metabolism is initiated (Hohnke \& Scheer 1970, Stetten 1982). The generally low glycogen values in hypoxic Nephrops norvegicus collected from the field reflect a shift to anaerobic metabolism which is particularly marked in hypoxic conditions (oxygen concentration $<12 \%$ saturation; Hagerman et al. 1990) while the low concentrations in lobsters from normoxic conditions in spring may be due to decreased feeding activity during winter (leading to depletion of energy reserves).

Hagerman \& Baden (1988) suggested that cessation of feeding behaviour (and resulting starvation) is the primary cause of low haemolymph haemocyanin concentrations in Nephrops norvegicus from hypoxic field locations (oxygen concentration $<15 \%$ saturation). Exposure to moderate and severe hypoxia was associated with loss of functional haemocyanin in the haemolymph (as indicated by a reduction in oxyhaemocyanin concentration measured spectrophotometrically), but little loss of copper. This finding is quite unexpected since most authors have previously indicated that if haemocyanin concentration decreases, so too will copper concentration (see e.g. Hagerman \& Weber 1981, Engel \& Brouwer 1987). Closer examination of earlier studies also provides evidence of haemocyanin changes independent of changes in haemolymph copper concentration. For example, Engel \& Brouwer's (1991) data indicate that during premoult (stage D4) in the blue crab Callinectes 
sapidus, oxyhaemocyanin concentration decreases while haemolymph copper concentration remains unchanged. How this occurs is unknown at present. Mangum (1993) has recently demonstrated that alterations in subunit composition and arrangement can affect the oxygen binding properties of decapod haemocyanin. If exposure to severe hypoxia in some way irreversibly damages the functional integrity of haemocyanin molecules, this could explain why copper concentrations in the haemolymph remain constant with exposure to hypoxia while measurements of functional oxyhaemocyanin indicate a decline. It is difficult to envisage free copper ions in haemolymph as such ions would bind non-specifically to protein (Depledge \& Bjerregaard 1989). An additional factor to note was that copper concentration decreased a little in lobsters in almost all experimental groups. This may be a non-specific response to stress (Depledge 1989b). As well as hypoxia, acute exposure to other stressors (such as elevated copper concentrations, acidification of fresh water) results in reduction of haemocyanin concentration in decapod crustaceans (Bjerregaard \& Vislie 1986, Depledge 1989b, F. Jensen pers. comm.)

Depledge \& Bjerregaard (1989) reviewed the literature concerning haemolymph haemocyanin and copper concentrations and tissue copper concentrations in decapod crustaceans undergoing starvation. In general, there is an inverse relationship between concentrations of copper in the haemolymph and in the midgut gland with changing nutritional state. As starvation proceeds, haemolymph copper (and haemocyaninj concentrations fall while midgut gland copper concentration increases (Djangmah 1970, Depledge 1989a). This translocation of copper from haemolymph to tissue was also found in Nephrops norvegicus exposed to long-term starvation.

Finally, it was intriguing to note that as copper concentrations and content fell in some tissues of the in situ lobsters, so manganese concentrations markedly increased. It is well known that when oxygen saturation falls below $16 \%$ reduced manganese is released from benthic sediments increasing bioavailability in bottom waters (Hall et al. 1989, Gerringa 1991). Conversely, the binding of copper to sediments increases in such circumstances (Santschi et al. 1990, Gerringa 1991). Manganese uptake and accumulation in lobsters was altered in hypoxic conditions such that tissue concentrations increased 3-fold (cf. Kattegat Nephrops norvegicus; Fig. 4). Deposition of manganese dioxide on the gills of $N$. norvegicus (taken from the same hypoxic area as examined in the present study) has been found to be so marked on some occasions as to give rise to a brown discolouration of the gills and black corroded areas on the carapace (Baden et al. 1990b). In the $N$. norvegicus used in the present study, there were no obvious signs of shell disease. Recently, Weinstein et al. (1992) reported high manganese concentrations in the brachyuran Callinectes sapidus from the Albemarle-Pamlico estuarine system in North Carolina, USA. This was associated with shell disease in crabs exposed to heary metal pollution. Internal tissues and gills of diseased crabs contained 2 to 8 times as much manganese as non-diseased crabs, while copper concentrations in the same tissues were always 2 to 3 times lower in diseased crabs (Weinstein et al. 1992). The crabs from the Albemarle-Pamlico estuarine system are also subjected to hypoxia at certain times of the year (West \& Ambrose 1992).

Whilst the details of the chemical and biological handling of copper and especially manganese are poorly known, previous reports have alluded to their interactions. With regard to the alga Thalassiosira pseudonana, for example, rising manganese ion availability increases accumulation and stimulates growth Simultaneous addition of copper, however, results in competitive inhibition of manganese uptake. Thus there appear to be shared pathways of manganese and copper entry and handling, at least in phytoplankton (Sunda \& Huntsman 1983)

The inverse relationship between copper and manganese concentrations in the tissues of lobsters in hypoxic field conditions and diseased crabs as well as the constancy of manganese load in lobsters treated in the laboratory clearly warrants further study.

Acknowledgements. The project was supported by the Danish Natural Science Council, grant no. 11-8391 (L.H.) \& grant no. 11-8993 (M.H.D.), the Swedish Council for Forestry and Agricultural Research grant no $40.0088 / 90$ (S.P.B.) and the Swedish Environmental Protection Board grant no. 26217 (S.P.B.). Thanks to Lene Hau and Susanne Eriksson for skilful technical assistance.

\section{LITERATURE CITED}

Antonini, E., Brunori, M. (1974). Transport of oxygen; respiratory proteins. In: Hayaishi, O. (ed.) Molecular oxygen in biology: topics in molecular oxygen research. NorthHolland, Amsterdam, p. 219-274

Atkinson, R. J. A., Taylor, A. C. (1988). Physiological ecology of burrowing decapods. Symp. zool. Soc. Lond. 59: 201-226

Baden, S.P., Loo, L.-O., Pihl, L., Rosenberg, R. (1990a). Effects of eutrophication on benthic communities, including fish, Swedish west coast. Ambio 19: 113-122

Baden, S. P., Pihl, L., Rosenberg, R. (1990b). Effects of oxygen depletion on the ecology, blood physiology and fishery of the Norway lobster Nephrops norvegicus (L.). Mar. Ecol. Prog. Ser. 67: 141-155

Bjerregaard, P., Vislie, T. (1986). Effects of copper on ion- and osmoregulation in the shore crab Carcinus maenas. Mar. Biol. 91: 69-76 
Butler, P. J., Taylor, E. W., McMahon, B. R. (1978). Respiratory and circulatory changes in the lobster (Homarus vulgaris) during long term exposure to moderate hypoxia. J. exp. Biol. 73: 131-146

Depledge. M. H. (1985). The influence of nutritional state on the circulatory and respiratory physiology of the shore crab, Carcinus maenas. J. mar. biol. Ass. U.K. 65: 69-78

Depledge, M. H. (1989a). Re-evaluation of metabolic requirements for copper and zinc in decapod crustaceans. Mar. environ. Res. 27: 115-126

Depledge, M. H. (1989b). The rational basis for detection of the early effects of marine pollutants using physiological indicators. Ambio 18: 301-302

Depledge, M. H., Bjerregaard, P. (1989). Haemolymph protein composition and copper levels in decapod crustaceans. Helgoländer Meeresunters. 43: 207-223

de Zwaan, A., Putzer, V. (1985). Metabolic adaptations of intertidal invertebrates to environmental hypoxia (a comparison of environmental anoxia to exercise anoxia). In: Laverack (ed.) Physiological adaptations of marine animals. The Company of Biologists, Cambridge, p. 33-62

Djangmah, J. S. (1970). The effects of feeding and starvation on copper in the blood and hepatopancreas and on blood proteins of Crangon vulgaris (Fabr.). Comp. Biochem. Physiol. 32: 709-731

Engel, D. W., Brouwer, M. (1987). Metal regulation and molting in the blue crab, Callinectes sapidus: metallothioneın function in metabolism. Biol. Bull. 173: 239-251

Engel, D.W., Brouwer, M. (1991). Short-term metallothionein and copper changes in blue crabs at ecdysis. Biol. Bull 180: $447-452$

Gerringa, L. J. A. (1991). Mobility of $\mathrm{Cu}, \mathrm{Cd}, \mathrm{Ni}, \mathrm{Pb}, \mathrm{Zn}, \mathrm{Fe}$ and $\mathrm{Mn}$ in marine sediment slurries under anaerobic conditions and at $20 \%$ air saturation. Neth. J Sea Res. 27: $145-156$

Hagerman, L. (1986). Haemocyanin concentration in the shrimp Crangon crangon (L.) after exposure to moderate hypoxia. Comp. Biochem. Physiol, 85A: (4). 721-724

Hagerman, L., Baden, S. P. (1988). Nephrops norvegicus: field study of effects of oxygen deficiency on haemocyanin concentration. J. exp. mar. Biol. Ecol. 1.16: 135-142

Hagerman, L., Sondergaard, T., Weile, K., Hosie, D., Uglow, R. F. (1990). Aspects of blood physiology and ammonia excretion in Nephrops norvegicus under hypoxia. Comp. Biochem. Physiol. 97A: 51-55

Hagerman, L., Szaniawska, A. (1990). Anaerobic metabolic strategy of the glacial relict isopod Saduria (Mesidotea) entomon. Mar. Ecol. Prog. Ser. 59: 91-96

Hagerman, L., Uglow, R. F. (1985). Effects of hypoxia on the respiratory and circulatory regulation of Nephrops norvegicus. Mar. Biol. 57: 273-278

Hagerman, L., Weber, R. E. (1981). Respiratory rate, haemolymph oxygen tension and haemocyanin level in the shrimp Palaemon adspersus Rathke. J. exp. mar. Biol

This article was submitted to the editor
Ecol. 54: 13-20

Hall, P. O., Anderson, L. G., Rutgers van der Loeff, M. M. Sundby, B., Westerlund, S. F. G. (1989). Oxygen uptake kinetics in the benthic boundary layer. Limnol. Oceanogr 34: $734-746$

Honke, L., Scheer, B. J. (1970). Carbohydrate metabolism in crustaceans. In: Florkin, M., Scheer, B. T (eds.) Chemical zoology, Vol. 5. Academic Press, New York, p. 147-166

Mangum, C. P. (1993). Structural and functional polymorphism of the haemocyanin $\mathrm{O}_{2}$ transport system of the sand fiddler crab, Uca pugilator. J. exp. mar. Biol. Ecol. 165: 133-141

Nickerson, K. W., van Holde, K. E. (1971). A comparison of molluscan and arthropod hemocyanin. I. Circular dichroism and absorption spectra. Comp. Biochem. Physiol. 39B: $855-872$

Rosenberg, R., Elmgren, R., Flescher, S., Jonsson, P., Persson, G., Dahlin, H. (1990). Marine eutrophication case studies in Sweden. Ambio 19: 102-108

Rosenberg, R., Hellman, B., Johansson, B. (1991). Hypoxic tolerance of marine benthic fauna. Mar. Ecol. Prog. Ser 79: $127-131$

Rydberg, L. (1987), Hydrography, nutrient and oxygen balance of the Kattegat and related phenomena. Ph.D. thesis, University of Göteborg

Santschi, P., Höhener, P., Benoit, G., Buchholtz-ten Brink, M. (1990). Chemical processes at the sediment-water interface. Mar. Chem. 30: 283-286

Sunda, W. G., Huntsman, S. A. (1983). Effect of competitive interactions between manganese and copper on cellular manganese and growth in estuarine and oceanic species of the diatom Thalassiosira. Limnol. Oceanogr. 28 (5): $924-934$

Stetten, M. R. (1982). Metabolism of glucose and glycogen in Limulus polypheum in vivo. Comp. Biochem. Physiol. 73: $803-813$

Stryer, L. (1988). Biochemistry, 3rd edn. Freeman \& Co., New York

Vooys, C. G. N. (1987). Adaptation to anaerobic metabolism in two mussel species, Mytilus edulis and Mytilus galloprovincialis, from the tidal zone at Arcachon Bay, France. Neth. J. Sea Res. 21: 17-23

Weinstein, J. E., West, T L., Bray, J. T (1992). Shell disease and metal content of blue crabs, Callinectes sapidus, from the Albemarle-Pamlico estuarine system, North Carolina. Arch. environ. Contam. Toxicol. 23: 355-362

West, T L., Ambrose, W. G. (1992). Abiotic and biotic effects on population dynamics of oligohaline benthic invertebrates. In: Colombo, G., Ferrar, I., Ceccherelli, V., Rossi, R. (eds.) Marine eutrophication and population dynamics. Proc. 25th Eur. Mar. Biol. Symp. Olsen \& Olsen, Fredensborg. p. $189-194$

Zar, J. H. (1984). Biostatistical analysis. Prentice-Hall, Inc., Englewood Cliffs

Manuscript first recelved: Aprll 29, 1993

Revised version accepted: October 14, 1993 